UDC 339.74

\author{
Вісин В.В., д.і.н., професор \\ Visyn V. Doctor of History, Professor \\ https://orcid.org/0000-0001-9122-9158 \\ Вісина T.M., к.і.н., доцент \\ Visyna T. Candidate of Historical Sciences, Associate Professor \\ https://orcid.org/0000-0002-0401-0594 \\ Марчук Н.M., магістр \\ Marchuk N. Master \\ Томчук I.M., магістр \\ Tomchuk I. Master
}

\title{
ПРОБЛЕМИ ТА ПРОТИРІЧЧЯ ФУНКЦІОНУВАННЯ СВІТОВОЇ ВАЛЮТНОЇ СИСТЕМИ
}

\author{
Луцький національний технічний університет
}

Статтю присвячено проблемам та протиріччям функціонування світової валютної системи в сучасних умовах.

На сучасному етапі наслідки глобальної фінансово-економічної кризи 2007-2008 рр. продовжують чинити негативний вплив на світову економіку, яка характеризується високим ступенем волатильності, нестійкості, неузгодженістю та суперечливістю економічної політики провідних держав, інтеграційних об'єднань і т.д. Такий стан загрожує новими ускладненнями в світовій економіці і характеризує їі майбутнє багато в чому невизначеним. Однією з головних причин цієї невизначеності є нестабільність світової валютної системи (МВС), обумовлена нерегульованим розширенням фінансових ринків та інструментів; лібералізацією потоків міжнародного капіталу; посиленням впливу транснаціональних фінансових інститутів на економіки країн, що розвиваються; доларизацією світової економіки. Таким чином, структурні принципи Ямайської валютної системи, розроблені в 60-і pp. ХХ століття в інтересах провідних розвинених країн, в першу чергу Сполучених Штатів Америки (США), перестали відповідати реаліям світової економіки. В цих умовах надзвичайно актуальною стає тема реформування МВС і регулювання міжнародних валютних відносин.

В статьї визначено основні слабкі та сильні сторони світового валютного ринку.

На основі проведеного аналізу встановлено, що міжнародний валютний ринок в нинішньому вигляді відображає реальний попит і пропозицію на різні валюти. Різкі коливання на ньому в кризовий період відображають звичайну поведінку його учасників, які вкладають кошти в валюти - притулку, i реальний попит і пропозиція, викликані тим, що інвестори виходять з угод з використанням позикових коштів. Таким чином, валютний ринок фактично функціонує нормально.

Доведено, що найближчим часом світову валютно-фінансову систему чекають будь-які серйозні кризові явища, немає підстав. Принципи ії побудови повністю відповідають принципам побудови структури світової економіки, розстановці сил на світовій арені і інтересам провідних економічних центрів і країн.

Статус долара США як основної резервної валюти не піддається сумніву. По-перше, для цього поки немає яких-небудь серйозних макроекономічних і статистичних підстав і причин. По-друге, зміни в цьому напрямку загрожують серйозними економічними проблемами для всіх країн, хоча мова про кризу всієї світової валютної системи (навіть при зміні статусу долара США) не йде.

Резумуючи статью можна стверджувати, основна резервна валюта в світі - долар США зберігає свою стійкість.

Ключові слова: валюта, валютна система, валютні відносини, валютний ринок.

\section{PROBLEMS AND CONTRADICTIONS OF THE WORLD MONETARY SYSTEM}

\section{Lutsk National Technical University}

The article is devoted to the problems and contradictions of the functioning of the world monetary system in modern conditions.

At the present stage, the consequences of the global financial and economic crisis of 2007-2008 continue to have a negative impact on the world economy, which is characterized by a high degree of volatility, instability, unfavorable and contradictory economic policies of leading states, integration associations and others. This situation threatens new applications in the world economy and reveals its future is largely uncertain. One of the 
main reasons for this uncertainty is the instability of the world monetary system (MIA), due to the unregulated expansion of financial markets and instruments; liberalization of international capital flows; increasing the impact of transnational financial institutions on the economies of developing countries; dollarization of the world economy. Thus, the structural principles of the Jamaican monetary system, developed in the 60's of XX century in the interests of leading developed countries, especially the United States (USA), ceased to correspond to the realities of the world economy. In these conditions, the topic of reforming the Ministry of Internal Affairs and regulating international monetary relations becomes extremely relevant.

The article identifies the main weaknesses and strengths of the global foreign exchange market.

Based on the analysis, it is established that the international foreign exchange market in its current form reflects the real demand and supply for different currencies. Sharp fluctuations in it during the crisis reflect the usual behavior of its participants, who invest in the currency - asylum, and real supply and demand, caused by the fact that investors withdraw from transactions using borrowed funds. Thus, the foreign exchange market is actually functioning normally.

It is proved that in the near future the world monetary and financial system will face any serious crisis, there is no reason. The principles of its construction are fully consistent with the principles of building the structure of the world economy, the balance of power on the world stage and the interests of leading economic centers and countries.

The status of the US dollar as the main reserve currency is not in doubt. First, there are no serious macroeconomic and statistical reasons for this yet. Secondly, changes in this direction threaten serious economic problems for all countries, although we are not talking about the crisis of the entire world monetary system (even when the status of the US dollar changes).

Summing up the article, we can say that the main reserve currency in the world - the US dollar remains stable.

Kеу words: валюта, валютна система, валютні відносини, валютний ринок.

Statement of the problem in general and its connection with important scientific and practical tasks. At the present stage, the consequences of the global financial and economic crisis of 2007-2008 continue to have a negative impact on the world economy. This situation threatens new complications in the world economy and characterizes its future is largely uncertain. One of the main reasons for this uncertainty is the instability of the world monetary system (MIA), due to the unregulated expansion of financial markets and instruments; liberalization of international capital flows; increasing the impact of transnational financial institutions on the economies of developing countries; dollarization of the world economy. Thus, the structural principles of the Jamaican monetary system, developed in the 60's of XX century in the interests of leading developed countries have ceased to correspond to the realities of the world economy. In these conditions, the topic of the functioning of the world monetary system becomes extremely relevant.

Analysis of recent research that has begun to solve the problem. Problems of the world monetary system has a long history and is represented in economics by numerous theories and economic schools. The works of the following scientists are devoted to the study of the problems of evolution and reform of the Ministry of Internal Affairs: D. Yuma, Dzh.M. Keynsa, R. Nyurkse, H. Kholma, Dzh. Vil'yamsa, H. Kasselya, H. Uindera, M. Fridmena, Dzh. Frenkel, X. Dzhonsona, Dzh. Fleminha, R. Mandella, YA. Tinberhena, R. Tryffina, A. Svobody, F. Khayyeka, R. Dornbush, P. Kutner, R. Miza, M.A. Panilova, D.I. Kondratova, V.V. Kuznyetsovoyi, S. YU. Hlaz'yeva, and others. However, the available theoretical achievements and practical experience were insufficient to meet the challenges of the economy of the XXI century, which led to the choice for a more in-depth study of the problem in the new environment.

Objectives of the article. The main goal is to study the problems of functioning and contradictions of the world monetary system.

Presentation of the main material of the research with substantiation of the obtained scientific results. Economic, political and ideological problems of countries cause the complexity and contradictions of the process of monetary integration. On the one hand, the inability, at the present stage, of countries to meet national needs independently, contributes to the development andintegration processes, on the other - different national interests of countries and the natural policy of protectionism lead to many problems in international relations. Thus, in recent years, disintegration processes in different regions of the world are intensifying. 
The current financial crisis has affected every country and every international market. Both those who were to blame for it and those who had nothing to do with the origins of its formation suffered from it.

The authorities of each country in their own way are trying to find a way out of the situation and are trying their best to support their own national economies. The problem is that financial authorities usually do not have ready-made economic methods for overcoming such global crises and they work according to the axioms that are written in any textbook on economics:

- prevent the complete collapse of the financial system in any way;

- provide sufficient liquidity;

- use the levers of fiscal and monetary policy.

However, there is one component of the capital market in which the state has not intervened - the international foreign exchange market. Questions arise: why has the currency crisis not happened yet, why has the global economic crisis not led to a currency crisis? Contrary to the opinion of some authors, the changes that have taken place in the international foreign exchange market over the past year cannot be called a crisis.

The strengthening of the US dollar from August 2008 to January 2009 against all other world currencies (except the Japanese yen) was quite large. For example, the euro lost $23 \%$ of its value against the dollar, the pound fell by almost 27\%, the Australian dollar, where the Reserve Bank of Australia intervened, lost a third [1].

From August 2008 to January 2009, its level was the highest in history: 25\% for the euro and $29 \%$ for the yen. The average level of volatility for the entire international foreign exchange market was about $20 \%$. These are quite high figures, if we compare them, for example, with the level of September 11, 2001, when these values were 2 times lower.

The considered events in the international currency market were perceived as a manifestation of the crisis of the world monetary system. But, in our opinion, the global financial crisis has only become a catalyst for discussing the current state of the global monetary and financial system.

Many believe that it has long gone bankrupt and is in fact at the stage corresponding to the situation in Germany at the end of 1923. The reason for this position is the debatable question of the possibility of the US dollar to maintain its status as a world reserve currency.

The fact is that the existing global financial system with the dollar as the world's reserve currency was created in an environment where similar actions were taken by only one group of countries - the Middle East, which trades in oil. The dollar is left alone, but now two groups of countries with good incomes but underdeveloped financial systems are pumping their money into the United States. China alone has accumulated more than \$ 1.7 trillion.

The danger was that if there was a crisis in emerging Asian economies, it would immediately bring down oil prices. Then both sources of pumping money into the American financial system would be shallow at the same time.

The second question, which is considered in the above context, is whether the US economy will be able to service its external debt.

Given the Fed's recent efforts, its concerns appear to have intensified significantly. The Fed's decision to pump trillions of dollars into money markets complements the US president's proposal to increase the federal budget to $20 \%$ of GDP through a huge loan to finance several anti-crisis projects, the health care system, the energy system and a number of other programs.

The President's promise that America will never default on its debt obligations has not calmed the markets: according to The Wall Street Journal, insurance against default by the US government on its obligations is now seven times more expensive than a year ago .

China and Japan already have significant stocks of long-term US Treasury bonds, the value of which has fallen sharply over the past year, which can not help but worry investors.

In addition, China is implementing a large investment program (amounting to more than 570 billion dollars), aimed at supporting the national economy. These acquisitions affect what was previously used to buy American securities. "Another big buyer - Japan - is currently 
reviewing the current account deficit, so it is unlikely to find enough efficiency for these purposes. What you can say about close incoming investors - the flow comes from the sale of oil much faster due to falling oil prices"[2, p. 2].

Not surprisingly, the former economic adviser to President George W. Bush L. Lindsay states that he "can not understand which groups of foreign buyers are going to buy debt" [3, p. $1]$.

This is confirmed by the figures for the movement of investment services across the US border. In April, this figure will be 11.5 billion dollars. USD, in May - already 19.8 billion dollars. USA. The general trend towards the crisis period is a multiple decrease in the inflow of foreign investment into the US economy.

On the other hand, it was the financial crisis in America that provoked in 2008 an escape to a quality asset that markets considered the dollar. The dollar came out of the financial catastrophe that engulfed US second-tier mortgages worth $\$ 1.3$ trillion. As a result of this crisis, the capitalization of world stock markets has shrunk by $\$ 32,000$ billion, and a recession has begun in all the leading industrialized countries of the G7. It was this fear factor that supported the demand for dollars in the first months of 2009.

At the moment, there is no clear alternative to the dollar, because in all major countries the recession has begun. Due to declining world trade and falling commodity prices, growth rates in emerging markets are declining sharply. In South Korea and Taiwan, the decline has reached serious proportions. Growth in China has already halved. "In these circumstances, investors need a strong international currency. They do not trust stocks, they do not trust corporate bonds, they doubt government bonds, and through foreign exchange markets they express their doubts about the economic prospects of individual countries "[4, p. 1].

Contrary to the opinion of some economists, who claim that there is an excess of US dollars in the world monetary system, what has happened in the last year is a lack of dollars. This is also confirmed by high interest rates on the dollar in many countries. The situation was aggravated by participants in the international foreign exchange market, who intensified the process of buying US dollars.

J. Keynes described this effect: "The point is not even that we choose people who are considered really beautiful by someone, or even people who are considered beautiful by the vast majority of society. We have reached the third level, when we try our best to imagine what the "average" person thinks about what the average opinion will be. And I think that there are those who are trying to reach the fourth, fifth level and above "[5, p. 105].

Keynes said that stock markets behave in a similar way. We do not buy company shares based on the perception of their intrinsic value. We buy company stock based on our perception of how others understand the intrinsic value of the company. The others do the same.

This situation can be applied to the foreign exchange market: each investor believes that everyone else is stockpiled in dollars. There is a shortage of dollars in the world.

This situation was resolved by the US Federal Reserve simply - began the active issuance of US dollars, supplemented by a sharp decline in the refinancing rate. The US government had to sell the Fed's T-bills in exchange for a significant increase in the dollar mass.

Only then did investors begin to think about domestic prices in the capital market. All this, of course, affected inflation, the level of which began to rise: in May, the consumer price index rose by only $0.1 \%$, and in June this figure was already $0.7 \%$.

On the other hand, financial market participants use the US dollar as a haven. All this draws attention to the following question: is it possible a situation of marginal risk associated with the collapse of the US financial system with all the consequences arising from global risks?

As mentioned above, many economists have noted that if the inflow of capital into the United States slows down, if, for example, Japan or OPEC countries enter a phase of economic crisis and stop investing their dollars in the United States, America will be immediately involved in the worst financial crisis. This means that the role of the buyer will go to the common American population and the Fed. 
Even if people make more savings, domestic demand will not be able to meet the increased supply of treasury bonds, and buying Fed bonds will lead to inflation. In recent years, a large number of works have been published on scenarios of the currency crisis, and various schemes of the future structure of the world monetary system have been proposed [6, p. 62].

Many of these concepts boil down to the euro replacing the US dollar as the world's reserve currency. For example, the former head of the Fed A. Greenspan believes that: "we are beginning to see a certain shift from the dollar to the euro, both on the part of the private sector and on the part of monetary authorities and central banks" [7, p. 1].

It is believed that the world credit and financial system is preparing to change the world currency. The dollar must give way to the euro as the pedestal of the world currency. The dollar itself, as the pound sterling once did, will remain simply a national currency. The result of the change of leader is a general decrease in the money supply in the world (due to the fall of the dollar) and bringing it in line with the commodity mass. Such a scenario, although wellfounded, has many debatable aspects.

First, the role of the euro today in the world monetary system is limited by the status of one of the reserve currencies. But the vast majority of international payments are made using the US dollar. There is no doubt that if the euro disappears tomorrow and the national currencies of the EU countries appear again, nothing terrible will happen to the world economy, but the collapse of the US dollar will lead to the collapse of the entire world monetary and financial system.

Second, recent macroeconomic and statistical data on the US economy indicate that America is recovering faster than others (Eurozone, UK, Japan) from the crisis. Moreover, despite the reduction in investment capital inflows to the United States, the trade deficit has more than halved: from - 58 billion dollars. in 2008 to - 30 billion dollars. US in 2009. Therefore, very soon the dollar may move from the status of the currency of the security zone to the status of a currency attractive from an investment point of view. As the pace of recovery (in terms of recovery) of the US economy becomes more apparent, the dollar may begin to strengthen again.

All this gives the right to believe that so far there are no reasons that would force participants in the international foreign exchange market to abandon the US dollar in its current status. Thus, we can only talk about the prospects of the US dollar, but to talk about the crisis of the entire world monetary system, in my opinion, is incorrect. Its main elements in a crisis, on the contrary, have proven their stability: the exchange rate, the conditions of currency convertibility, the regimes of world currency markets, etc.

The events of the last year in the world economy have shown that countries should either let their currencies float freely or adopt another currency that will fluctuate freely relative to all others outside the union. Against this background, the question of the so-called new Bretton Woods is controversial. The basis for the reorganization of the existing world monetary and financial system should be measures that lay the foundation for a new, non-speculative, economy.

One aspect of reforming the existing model of international monetary and financial relations should be to address the issue of developing new rules to ensure the stability necessary for production and international trade. To this end, it is proposed to set exchange rates by agreements between states ("fixed exchange rates") in order to avoid speculative market fluctuations and to introduce control over the movement of capital for speculative purposes ("capital control").

These issues were discussed during the G7 meeting, but no systemic decisions were made. This is because aspects of the new Bretton Woods are very difficult to implement in practice. In addition, the main participants in the global monetary and financial system do not see serious grounds for its reform. What is happening in the international foreign exchange market can only be called a consequence of the global financial crisis.

As already noted, the growth of the US dollar is due to the fact that it serves as a currency of refuge. At the same time, it would also be fair to point to the second reason for such a large- 
scale strengthening of the US currency. Some economists note [8, p. 3], which is based on the current financial crisis is a leverage-double accrual of compound interest. This leverage was financed mainly by the dollar, the yen and, to a lesser extent, the Swiss franc and the Hong Kong dollar. The dollar and yen were borrowed and converted, and then lent everywhere.

As a result, we got a significant short position on the dollar and yen, which needs to be closed. The strengthening of the dollar and yen is a reflection of a very real global margin requirement. This is exactly what is trying to distribute their growing value. Part of the leverage arose as a result of currency mismatch, and the refusal to use it was one of the most influential forces that led to the growth of the dollar and yen.

If the ubiquitous leverage process has contributed to an unprecedented rise in major currencies other than the yen relative to the PPP's stable frontiers (currency purchasing power parity), the reverse process is pushing currencies, including the yen, back into the PPP.

Therefore, based on these statements, it is advisable to analyze the global foreign exchange market to identify the main problems of its operation and possible ways to eliminate them (table 1)/

Table 1

Swot-analysis of the world currency market

\begin{tabular}{|c|c|}
\hline Strengths & Weak sides \\
\hline $\begin{array}{l}\text { - simplified access to foreign exchange transactions; } \\
\text { - increasing the volume of national financial markets and } \\
\text { reducing the level of their monopolization; } \\
\text { - reducing the cost and improving the location of domestic } \\
\text { borrowing resources; } \\
\text { - optimization of access to long-term revenues to the } \\
\text { domestic financial market and foreign expansion } \\
\text { investment; } \\
\text { - supplementing the internal accumulation of capital by } \\
\text { increasing foreign investment, as well as technical re- } \\
\text { equipment of production and staff training; } \\
\text { - stimulating the economic growth of the recipient country } \\
\text { and improving the welfare of its population. }\end{array}$ & $\begin{array}{l}\text { - shocks on world markets; } \\
\text { - dominance of foreign banking capital in the domestic } \\
\text { financial market; } \\
\text { - shortcomings of the legislation in the financial sphere; } \\
\text { - underdeveloped infrastructure of the foreign exchange } \\
\text { market; } \\
\text { - the spread of negative expectations through socio-political } \\
\text { events and military conflict; } \\
\text { - high level of domestic and foreign debt; } \\
\text { - high dependence on imports energy carriers; } \\
\text { - excessive influence of foreign capital on economic } \\
\text { development. }\end{array}$ \\
\hline Opportunities & Potential threats \\
\hline $\begin{array}{l}\text { - the ability to attract powerful investments from other } \\
\text { countries; } \\
\text { - use experience of developed markets for faster } \\
\text { introduction of new ones information and financial } \\
\text { technologies; } \\
\text { - significant implementation potential new financial } \\
\text { services; } \\
\text { - development of new financial products, technologies and } \\
\text { innovations after the arrival of foreign capital. }\end{array}$ & $\begin{array}{l}\text { - violation of macroeconomic stability due to increased } \\
\text { sensitivity to external shocks; } \\
\text { - cyclical movement of foreign short-term capital and } \\
\text { sudden reversal of capital; } \\
\text { - the probable concentration of foreign investment in certain, } \\
\text { mainly raw materials, sectors of the economy in their } \\
\text { absence in other sectors (the so-called "Dutch disease } \\
\text { syndrome"); } \\
\text { - uncertainty regarding macroeconomic policy and structural } \\
\text { reforms; } \\
\text { - deterioration of the investment climate, insufficient growth } \\
\text { rates investments; } \\
\text { - in conditions of significant import dependence } \\
\text { leads to an increase in inflationary pressure. }\end{array}$ \\
\hline
\end{tabular}

Source: [8]

Conclusions. The international foreign exchange market in its current form reflects the real demand and supply for different currencies. Sharp fluctuations in it during the crisis reflect the usual behavior of its participants, who invest in the currency - asylum, and real supply and demand, caused by the fact that investors withdraw from transactions using borrowed funds. Thus, the foreign exchange market is actually functioning normally.

There is no reason to claim that in the near future the world monetary and financial system will face any serious crisis phenomena. The principles of its construction are fully consistent with the principles of building the structure of the world economy, the balance of power on the world stage and the interests of leading economic centers and countries.

The status of the US dollar as the main reserve currency is not in doubt. First, there are no serious macroeconomic and statistical reasons for this yet. Secondly, changes in this direction threaten serious economic problems for all countries, although we are not talking 
about the crisis of the entire world monetary system (even when the status of the US dollar changes).

Thus, the international foreign exchange market is one of the components of the capital market, which operates without capital intervention. It should be noted that financial crises can provoke an escape to a quality asset. The events of the last year in the world economy have shown that countries should either release their currencies or adopt another currency that will fluctuate freely relative to all others.

At the same time, the main reserve currency in the world - the US dollar - retains its stability: currency exchange regime, conditions of currency convertibility, world currency market regimes, etc.

\section{References:}

1.International Monetary Fund : офіц. сайт. Washington, 2010-2016. URL: http://www.imf.org .

2.Jonathan Huntley, CBO Macroeconomic Analysis Division. - Congressional Budget Office, Figure 1 of "Federal Debt and the Risk of a Fiscal Crisis", July 272010.

3.Obstfeld Maurice. Risk and Exchange Rates. NBER. Working paper. 1998. № 6694. 19 p.

4.The Economist. Link by Link: A Short History of Modern Finance. London, 2008 October 16th, pp. 79-81. Available via: http://www.economist.com/displaystory.cfm?story_id=12415730 .

5. King, S. Terrible results of the economic beauty contest: Forex market news, 2012. URL: Forexpf.

6. Yaremenko O.O. Features of the concept of "currency regulation" in modern economic conditions. Investments: practice and experience, 2011. №21. Pp. 102-105.

7. Butorina, O.N. Upcoming changes in the international monetary system: Exchange Review, 2014. №4. Pp. 20-35.

8. Bodrova N.E. Currency market: status, problems, prospects, 2012. 103 p.

Дата подання публікації 10.10.2021p.

\section{УДК 339.944:004.9}

Кривов’язюк I.В., к.е.н., професор Професор кафедри підприємництва, торгівлі та логістики Kryvovyazyuk I., PhD in Economics, Professor Professor of the Department of Entrepreneurship, Trade and Logistics https://orcid.org/0000-0002-8801-4700

\section{ФАКТОРИ УСПІХУ МІЖНАРОДНИХ СТРАТЕГІЧНИХ АЛЬЯНСІВ У IT-СФЕРІ В УМОВАХ ПОШИРЕННЯ СОVID-19}

\section{Луцький начіональний технічний університет}

Міжнародний бізнес в IT-сфері займає все більшу й більшу частку світового ринку, значною мірою завдячуючи розвитку міжфірмової інтеграції, формуванню міжнародних стратегічних альянсів. Реалізація міжгалузевих інноваційних проєктів, формування нових умов взаємодії держав і бізнесу, технологічна інтеграція науки та виробництва дозволяють успішно долати бар'єри економічних блоків і кордони країн, освоювати нові міжнародні ринки збуту.

В науковій статті було вирішене складне завдання - здійснити видову класифікацію факторів успіху міжнародних стратегічних альянсів у IT-сфері в умовах поширення COVID-19. Незважаючи на значну кількість публікацій, присвячених проблематиці формування та розвитку міжнародних стратегічних альянсів, іiі розкривали частково, визначаючи предметну суть стратегічних альянсів, організаційно-правові умови їх формування, переваги й недоліки створення, особливості управління. Зовсім не вирішеною така проблематика постала для сучасних умов - поширення COVID-19. Й не менш важливим $є$ визначення факторів, які сприяють успіху стратегічних альянсів на міжнародних ринках. 